\title{
Project Method Efficiency for the Teachers' Professional Activities
}

\author{
Oleksandr Kobernyk ${ }^{1, *}$, Nataliia Kolomiiets ${ }^{2}$, Olha Komar ${ }^{3}$, Liudmyla Roienko ${ }^{3}$ \& Liubov Baidiuk ${ }^{3}$ \\ ${ }^{1}$ Pedagogics and Education Management Department, Faculty of Social and Psychological Education, Pavlo \\ Tychyna Uman State Pedagogical University, Uman, Ukraine \\ ${ }^{2}$ Education Technologies and Pedagogic Creativity Department, Faculty of Primary Education, Pavlo Tychyna Uman \\ State Pedagogical University, Uman, Ukraine \\ ${ }^{3}$ Professional Methodologies and Innovative Technologies in Primary School Department, Faculty of Primary \\ Education, Pavlo Tychyna Uman State Pedagogical University, Uman, Ukraine \\ *Correspondence: Pavlo Tychyna Uman State Pedagogical University, 2, Sadova Str., Uman, 20300, Ukraine. E-mail: \\ kobernykolks78@gmail.com
}

Received: December 7, 2021

Accepted: January 6, 2022 Online Published: January 17, 2022

doi:10.5430/jct.v11n1p73

URL: https://doi.org/10.5430/jct.v11n1p73

\begin{abstract}
The relevance of the study is based on the discrepancy between the need for the project management program-methodical support and insufficient development in pedagogical practice. Aims. The aim of the study is to examine the effective development and implementation of the project method in the HEI from the standpoint of pedagogy as a new type of educational process management. Methods: questionnaire methods and pedagogical observation methods. The following questionnaires were used. E. Torrance's "Tests of Creative Thinking" method. An "unfinished thesis" method (J. Sachs, S. Levy). Questionnaire for self-evaluation of the teacher's knowledge and skills during transition to teaching using a new pedagogical technology by N.V. Nemova. Method for teacher's basic competencies evaluation by L.A. Adambaeva. Statistical calculations were performed using Kendall's T coefficient and chi-squared test. Results. The number of students with a high level of personality orientation increased only by $5.3 \%$, and those with a high level of creative activity - by $8.7 \%$. We can't speak about a significant decrease in the number of students who at the end of the experiment had a low level of the aesthetic position formation. Thus, the number of students who showed developed creative thinking in project activities became only $5.3 \%$ less than at the beginning of the experiment. Conclusions. A significant increase in the general level of cognitive competence formation in the experimental group in comparison with the control group is explained by purposeful work with students, taking into account special pedagogical conditions. Perspectives. Further study can be carried out towards the development and implementation of a project method to improve the competencies acquisition, taking into account future professional activities.
\end{abstract}

Keywords: teacher's work, project method, competencies acquisition, professional competence, professional activity

\section{Introduction}

The relevance of the study at the socio-pedagogical level is determined by the social need of society for a highly qualified and effective system of future specialists' training. The relevance of the article at the scientific methodological level is based on the discrepancy between the need for the project management program-methodical support and insufficient development in pedagogical practice. That is why it is important for the HEI teacher to use modern and effective methods of preparing students for solving problems. A graduate by the time of graduation should have skills of the twenty-first century. These skills are essential for solving complex problems: teamwork, problem solving, statistics collection, time management, information synthesis, use of high-tech tools. It is also very important that students should be able to take responsibility for their own training (Zukhra et al., 2020).

The transition to new educational standards sets new tasks for the HEI: the search and implementation of pedagogical techniques, teaching methods into the educational process, ensuring the development of competitive specialists that meet the requirements of the modern labor market. Since the traditional educational system is based on the transfer of ready-made knowledge, it comes down to solving theoretical and practical problems according to given algorithms and schemes, it remains little focused on students' self-improvement and self-development. The 
problem arises in finding effective ways to high-quality training of new level professionals. One of such tools is the project method, which, as a pedagogical technique, includes a set of research, search, problematic methods that are creative in nature (Soomro et al., 2018).

The term "project" translated from the Latin "projectus" means "thrown forward", in dictionaries it is defined as "a plan, concept, prototype, activity type". In the academical literature, the project method has different meanings: a teaching method, a type of educational activity.

Over the past decade, project-based learning has been increasingly tested and a variety of educational institutions around the world has chosen it. In the higher education segment, project-based learning is much more common in engineering. Recently, the project-based approach to learning has developed significantly. Students entering educational institutions or online courses clearly understand that their task is to acquire certain knowledge and skills. Motivating such students is a challenging task for teachers at the higher education level (Popel, 2018).

Creative academic subjects such as project-based learning replace years of passive learning practices that students no longer provide feedback on. Interdisciplinary research is not unique today. Project-based learning improves the global perspective as well as the flexible communication common in the student community. Technology, combined with progressive teaching strategies, dissolves traditional learning approaches, and the nature of learning becomes more and more understandable for different students (Anisimova, 2020).

Lifelong learning becomes the norm. Projects are complex tasks based on solving important problems. It engages students in development, problem-solving, decision-making, or research activities. Students can work relatively independently, over a long period of time, completing the work by creating real products or presenting solutions to complex issues. In terms of project, not only the object is seen, but the entire system of connections around the future object (Bakirova, 2021; Plomp, 2020).

The use of projects and educational activities made it possible to determine the learning technology that should be used by the teacher in the educational environment when involving students in projective work. This technology implements creative didactics, which differes from the traditional (reproductive) one (Table 1).

Table 1. Differences between Traditional and Creative Didactics

\begin{tabular}{|c|c|c|}
\hline \multirow[t]{2}{*}{ TRAINING ELEMENTS } & \multicolumn{2}{|r|}{ TYPE OF DIDACTICS } \\
\hline & Reproductive & Creative \\
\hline Problem statement by the teacher & Object & Functional \\
\hline Solution method & $\begin{array}{l}\text { Precisely defined and } \\
\text { indicated by the teacher }\end{array}$ & $\begin{array}{l}\text { The student chooses solution methods, } \\
\text { uses a variety of heuristic techniques, } \\
\text { strategies, methods, tactics }\end{array}$ \\
\hline Training example & $\begin{array}{l}\text { The prototype } \\
\text { provided by the teacher }\end{array}$ & $\begin{array}{l}\text { The student discovers and uses } \\
\text { similarities of properties and relationships in } \\
\text { animated and inanimate nature, society }\end{array}$ \\
\hline Result for the teacher & Clear and definite & $\begin{array}{l}\text { Significant and unknown (new knowledge is } \\
\text { formed) }\end{array}$ \\
\hline
\end{tabular}

Source: Prepared by the authors based on Alvarez-Napagao (2021).

The project method of teaching almost always ensures that it will be interdisciplinary field of activity. Now there are no clear requirements for the teacher, the organizer of students' project activities. The teacher's role is to act as a mentor and project coordinator. He should encourage students to use a variety of sources using an interesting and motivating teaching strategy. This is nothing more than the art of managing the educational process at a tactical level (Carbonell Alcaina et al, 2021). Here, one should take into account the difference between traditional methods and project methods in the teacher's professional activity (Table 2). 
Table 2. Difference between Traditional Methods and Project Methods in the Teacher'S Professional Activity

\begin{tabular}{|c|c|c|}
\hline $\begin{array}{l}\text { COMPARISON } \\
\text { CRITERION }\end{array}$ & TRADITIONAL & PROJECT \\
\hline Function & Dominant & Service \\
\hline Teacher's role & The student is the learning object & $\begin{array}{l}\text { The student is the leading subject of the educational } \\
\text { process. He independently selects the necessary } \\
\text { information, determines the importance level based on } \\
\text { the project concept }\end{array}$ \\
\hline Education content & $\begin{array}{l}\text { Ready, systematized knowledge is } \\
\text { subject to assimilation }\end{array}$ & $\begin{array}{l}\text { The student independently establishes the truth. } \\
\text { Knowledge can be random, unsystematic, as a rule, } \\
\text { not true and contradictory }\end{array}$ \\
\hline Technology focus & $\begin{array}{l}\text { The student learns the knowledge, } \\
\text { skills and abilities system }\end{array}$ & The student builds his project, his idea of the world \\
\hline $\begin{array}{l}\text { The main element of the } \\
\text { learning process }\end{array}$ & $\begin{array}{l}\text { The main element of the educational } \\
\text { process is knowledge. Knowledge, } \\
\text { verified by the society practice, is the } \\
\text { result of knowledge of reality, it is } \\
\text { true and consistent }\end{array}$ & $\begin{array}{l}\text { The main element of the educational process is not } \\
\text { knowledge, but information. Information - data of any } \\
\text { nature, expressing the speakers' opinions, is not } \\
\text { always reliable and, as a rule, does not coincide or } \\
\text { even contradict each other }\end{array}$ \\
\hline
\end{tabular}

Source: Prepared by the authors based on Kalamaj (2019).

Thus, the relevance of this study is determined by the complex of existing contradictions between:

1. the need to develop student team management skills, both on the part of students and teachers, and the lack of theoretical and practical methods in this area;

2. the HEI requirements for the student projects and their insufficient development from the point of view of management at the teacher's level.

The aim of the study is to examine the effective development and implementation of the project method in the HEI from the standpoint of pedagogy as a new type of educational process management.

Objectives:

1) to study the theoretical aspects of the educational process management problem at the tactical level;

2) to identify the teachers' readiness to organize and manage the students' project activities;

3 ) to identify the level of students' readiness for project activities.

\subsection{Literature Review}

Many native and foreign researchers researched the issue of the project method efficiency. Anishchenko et al. (2019) in their work consider the theoretical basics of the project method organization. The authors pay special attention to the project method implementation in the educational process. The work covers the main problems of method implementation and common ways their solving. Boychuk (2021), among innovative techniques for the training of future teachers, pays special attention to the project method. The author notes that among all innovative methods, this method is the most efficient. Many scholars studied highly specialized applications of the project method. So, Bondar (2021) highlighted the issue of applying the project method for communicative competencies training when studying a foreign language. The pedagogical conditions for the project techniques implementation in universities are considered in the work of Weintraub (2016). As an example, the author gives the course "Technical creativity methods". An important role belongs to the issue of training projective competencies in future teachers. This topic is present in the work of Gontarenko (2016). The author draws attention to the didactic foundations of project competencies training. The work presents techniques for such implementation and methods of efficiency monitoring. The need to introduce distance learning was a challenge for many educational institutions. Along with new social restrictions, numerous pedagogical, psychological, didactic, methodological problems of educational process organisation arose. Drozdova et al. (2021) work discusses the introduction of project methods in the distance education system. The author examines both the method efficiency and the ways of its successful implementation. The works of Drozdova et al. (2021) and Koval (2019) study the project method application features in the study of 
foreign languages during distance learning. Kalamaj (2019) considers the issues of psychological factors that influence the project method implementation. The project method importance in the professional competencies training is discussed in the works of Arici et al. (2019), Gary (2015), Ibáñez and Delgado-Kloos (2018) and Karabaevna et al. (2020) consider the issues of project method using in shaping the future engineers' technical thinking. The comparison of innovative methods with traditional ones is highlighted in the article of Martin and Padula (2018), Postholm (2016) studies collaboration between teachers and schools to improve education.

The study analysis showed that the project method does not presuppose the individual knowledge and skills acquisition by students, but their complex learning. In this regard, the system of approaches to training is defined in a different way. The selection and design of learning approaches is based on the relevant competencies structure and the functions they perform in education. Most authors agree that the HEI is not able to present a level of students' competence sufficient to effectively solve problems in all areas and in all specific situations, especially in a rapidly changing society. Thus, the HEI goal is key competencies training. The study of the extracurricular activities in the cognitive competence training requires special attention; a properly organized system of extracurricular activities can develop the cognitive needs and abilities of each student.

\section{Methods}

\subsection{Research Design}

The research was carried out in several stages presented in Table 3.

Table 3. Research Design

\begin{tabular}{|c|c|c|c|}
\hline Research stages and their tasks & Stage duration & Methods & Respondents \\
\hline $\begin{array}{l}\text { SUMMATIVE STAGE: } \\
\text { - development of an experiment plan; } \\
\text { - development of pedagogical conditions for } \\
\text { the educational competence acquisition using } \\
\text { project method; } \\
\text { - determination of the students' educational } \\
\text { competence initial level. }\end{array}$ & $\begin{array}{l}\text { September } 2019 \\
-\quad \text { December } \\
2019\end{array}$ & $\begin{array}{l}\text { Questionnaire for self-evaluation of } \\
\text { the teacher's knowledge and skills } \\
\text { during transition to teaching using a } \\
\text { new pedagogical technology by N.V. } \\
\text { Nemova. Method for teacher's basic } \\
\text { competencies evaluation by L.A. } \\
\text { Adambaeva. }\end{array}$ & $\begin{array}{l}270 \text { students, } \\
30 \text { teachers }\end{array}$ \\
\hline $\begin{array}{l}\text { FORMATIVE STAGE } \\
\text { - verification of the pedagogical conditions for } \\
\text { the project method successful functioning }\end{array}$ & $\begin{array}{l}\text { January } 2020- \\
\text { December } 2021\end{array}$ & $\begin{array}{l}\text { An "unfinished thesis" method (J. } \\
\text { Sachs, S. Levy). }\end{array}$ & $\begin{array}{l}270 \text { students, } \\
30 \text { teachers }\end{array}$ \\
\hline $\begin{array}{l}\text { CONTROL STAGE: } \\
\text { - evaluation of the pedagogical conditions } \\
\text { efficiency for the project method functioning; } \\
\text { - processing the questionnaire results, summing } \\
\text { up and preparing recommendations and a plan } \\
\text { for further research. }\end{array}$ & $\begin{array}{l}\text { January } 2021- \\
\text { May } 2021\end{array}$ & $\begin{array}{l}\text { Questionnaire for self-evaluation of } \\
\text { the teacher's knowledge and skills } \\
\text { during transition to teaching using a } \\
\text { new pedagogical technology by N.V. } \\
\text { Nemova. Method for teacher's basic } \\
\text { competencies evaluation by L.A. } \\
\text { Adambaeva. }\end{array}$ & $\begin{array}{l}270 \text { students, } \\
30 \text { teachers }\end{array}$ \\
\hline
\end{tabular}

Source: Prepared by the authors

\subsection{Sample}

The main entity was made up of students studying in the Ukrainian HEIs. The research involved 270 students of 1-4 year from the Pedagogical Institute and the Institute of Arts of Borys Hrinchenko Kyiv University. The research also involved 30 teachers from the above-mentioned institutes. In the process of the pedagogical experiment, a randomized sample of two students' groups was compiled, taking into account approximately equal previous achievements and potential opportunities to continue their education. The control group studied according to the traditional method, which gave the opportunity to carry out a comparative study of the project activity efficiency using previously approved methods. Such sample results suggest that the research data are valid and reliable. 


\subsection{Methods}

1. E. Torrance's "Tests of Creative Thinking" method. The test is a technique for studying creativity and realizing the individual's creative potential.

2. An "unfinished thesis" method (J. Sachs, S. Levy) was used to determine the communicative level.

3. Questionnaire for self-evaluation of the teacher's knowledge and skills during transition to teaching using a new pedagogical technology by N.V. Nemova. Method for teacher's basic competencies evaluation by L.A. Adambaeva. The respondents were asked to assess the levels of knowledge, ability to develop program and methodological support and the ability to solve practical problems according to the following criteria:

0 - I have no idea about this knowledge and skills;

1 - I have some idea about this knowledge and skills;

2 - I have some knowledge and skills, but it is not enough for the successful implementation of a new technique;

3 - I have knowledge and skills, which, most likely, will be sufficient for the successful implementation of a new technique;

4 - I have knowledge and skills sufficient for the successful implementation of the new technique.

4. Two statistical hypotheses were generated. The null hypothesis (H0) assumes that the difference between the Oexp $i$ and Ocontrol i measured data is insignificant for all levels of $i=\{1,2,3\}$ item. The alternative hypothesis (H1) assumes that the values of the Oexp i and Ocontrol i differ from each other at the statistical significance level. To test the generated null hypothesis (H0) using the $\chi^{2}$ nonparametric coefficient. The value of the Kendall $\mathrm{T}$ statistical coefficient was generated using the formula:

$$
\mathrm{T}=\frac{1}{n 1 * n 2} \sum_{i=1}^{3} \frac{(n 1 * 0 \operatorname{exp~i-n~} 2 * 0 \text { control i })^{2}}{\text { Oexp i Ocontrol } \mathrm{i}}
$$

where $n 1 * n 2$ - respectively, the number of participants in the control and experimental groups;

Oexp i (Ocontrol i ) - the number of participants in the control and experimental groups who found themselves in one of the groups;

$\mathrm{i}=1$ corresponds to a high level of the aesthetic position, $\mathrm{i}=2$ - an average level, $\mathrm{i}=3-\mathrm{a}$ low level.

The quantitative data obtained as a result of the study are ranked, i.e. measured according to a rank scale. Chosen $\chi^{2}$ coefficient was generated using the formula:

$$
\chi^{2}=\left(f_{1}-f_{2}\right)^{2} /\left(f_{1}+f_{2}\right)
$$

\subsection{Instruments}

For the survey, Google Forms was used. Data entry and processing were made using Microsoft Excel and SPSS Statistics 18.0. All data are given in relative ( $\%$ of the respondents' number) values.

\section{Results}

Analysing the cognitive component of educational activity, all the knowledge gained by students during studying the didactic complex subjects was assessed in accordance with the strength of knowledge, the completeness and consistency of the studied and learned material. The Torrance test identifies the activity component level of the future bachelor's aesthetic position. The results obtained are shown in Figure 1.

Based on the research, creative potential integral assessment is made after measuring all its constituent characteristics, which significantly increases the reliability of obtained results. Based on the data obtained, it was found out that by the end of the experiment the overwhelming majority of students - the experimental group participants - had a focus on creative productivity (high + average level: $84.7 \%$ ) and showed a high degree of creative thinking $(87.9 \%) .80 .8 \%$ of students at high and average levels trained the ability to highlight the main thing, to understand the essence of the problem, and $77.8 \%$ of the respondents could stay open to novelty and a variety of ideas for a long time. Data analysis showed that the majority of students show a high level of creative activity when using the project method in teaching. 
The students' communicative level, determined by the ability to accumulate and use the creative experience of others, the ability to cooperate, was initially estimated only by the results of teachers' observation. Comparing the results of teachers' observations and students' test answers, a diagram was drawn up in Fig. 2, reflecting the idea of the communicative component level.

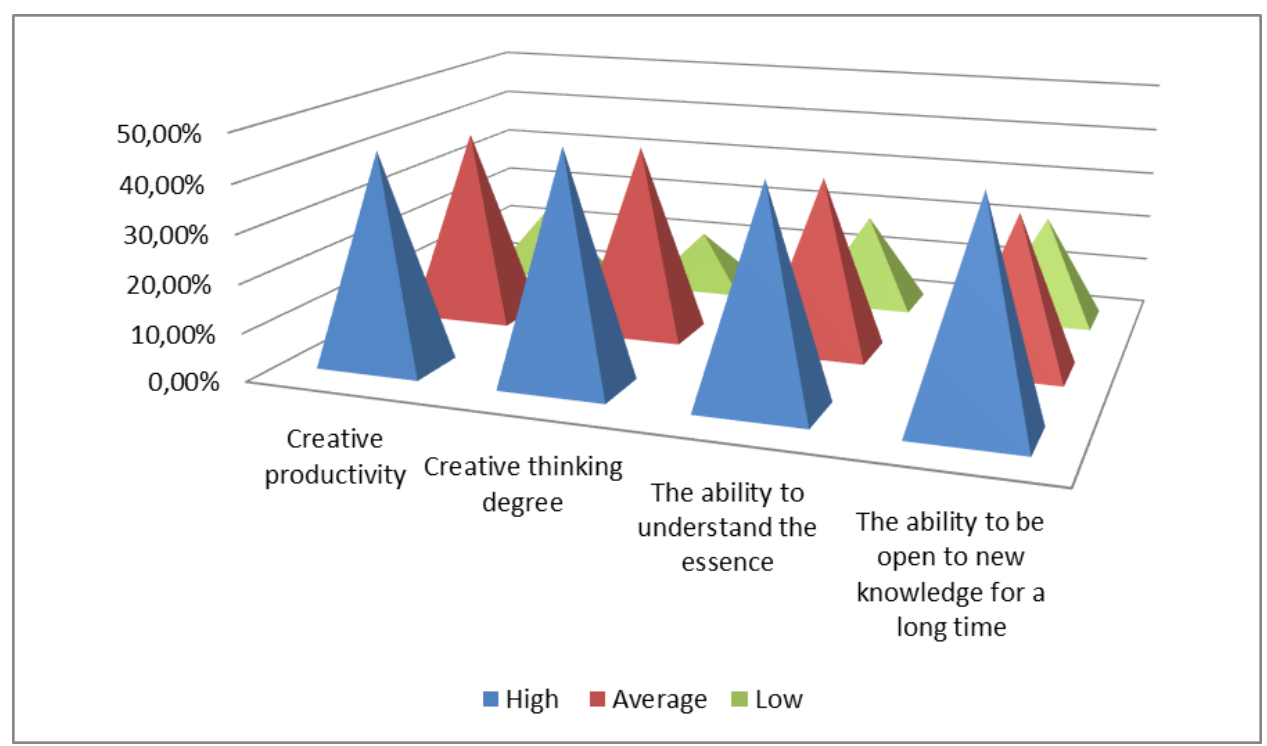

Figure 1. Distribution of the Respondents According to the Cognition Activity Component Levels When Using the Project Method in the Teachers' Professional Activities

Source: Prepared by the authors based on the research results

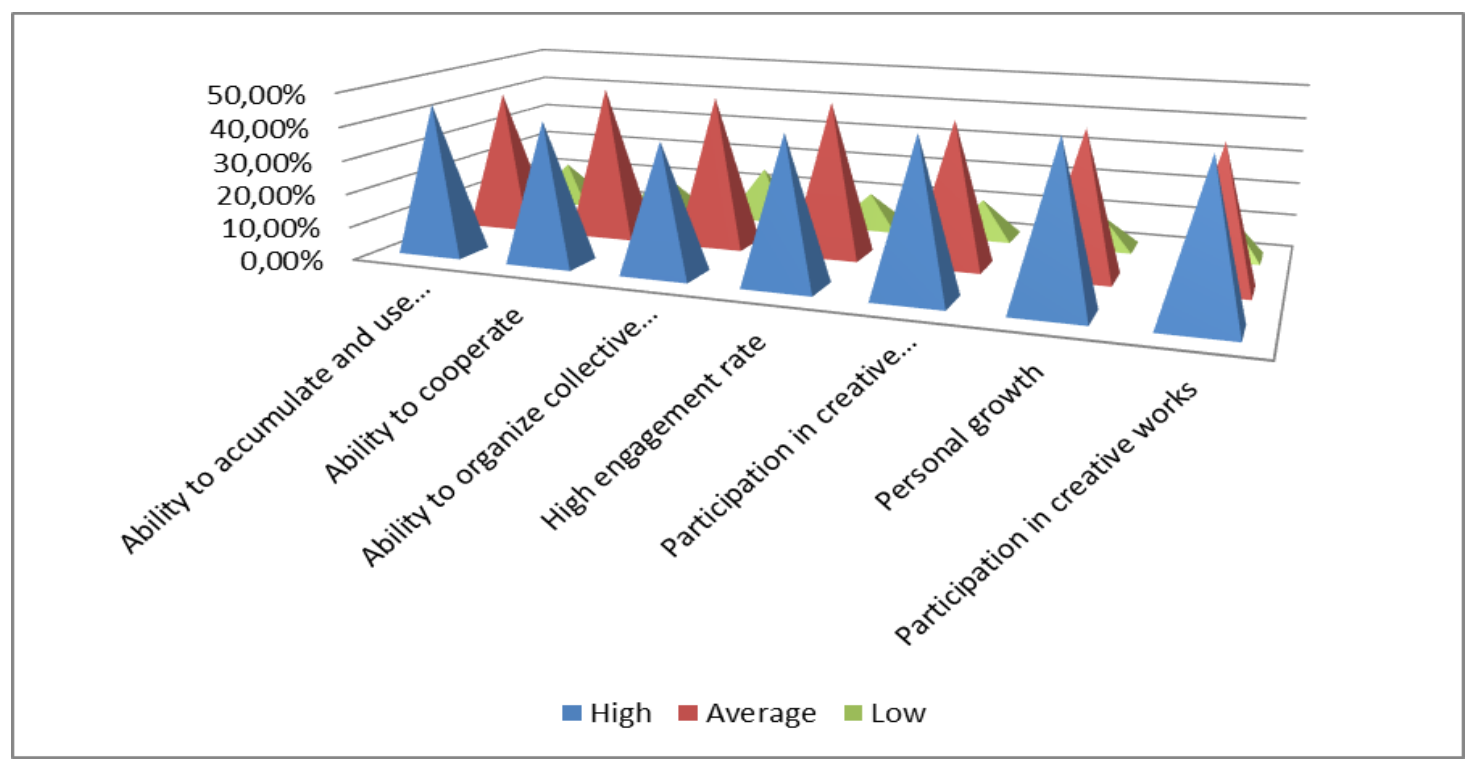

Figure 2. Distribution of the Respondents According to the cognitive Activity Communicative Component Level When Using the Project Method in The Teachers' Professional Activities

Source: Prepared by the authors based on the research results

Data analysis shows that, on average, $89.5 \%$ of the respondents have the ability to accumulate and use the experience of others at the proper level, $88.3 \%$ of the respondents show the ability to cooperate, productive communication and mutual assistance, $84 \%$ - the ability to organize collective activities and $89,5 \%$ - have a high level of information 
and communication involvement. $88.7 \%$ of students show participation in creative project activities, personal growth is noted in $90.5 \%$ of students, $86.8 \%$ are involved in creative work. In general, we can talk about a high level of cognitive activity communicative component among students when using the project method in teaching.

When carrying out project activities during the didactic complex implementation, students were divided into groups of 4-5 people, which provided conditions for the deep emotional contact between them, for productive communication and mutual assistance, as well as a stimulating competition situation. The individual form of work with each student, especially at the previous stage, has also proven to be successful. At the same time, the frontal form of project activities organisation in comparison with others was effective only at the stage of setting the tasks of project activities. Students showed a high level of cognitive competence during various events (lectures, seminars, individual work). The dynamics of the gnoseological competencies training was revealed at the beginning and end of the study (on a 1-10 scale). The research showed a positive development dynamics of all cognitive activity components in all experimental group participants.

The data show that by the end of the research, the number of respondents with a high and average level of cognitive competence increased significantly. It was noted that there were 2.5 times more students with a high level of cognitive competence than at the beginning. The number of experimental group participants with a low level of cognitive competence decreased 3.4 times. After the analysis, the final diagrams were drawn up (Fig. 3 and Fig. 4). They show the distribution of experimental and control groups' participants according to the cognitive competence levels.

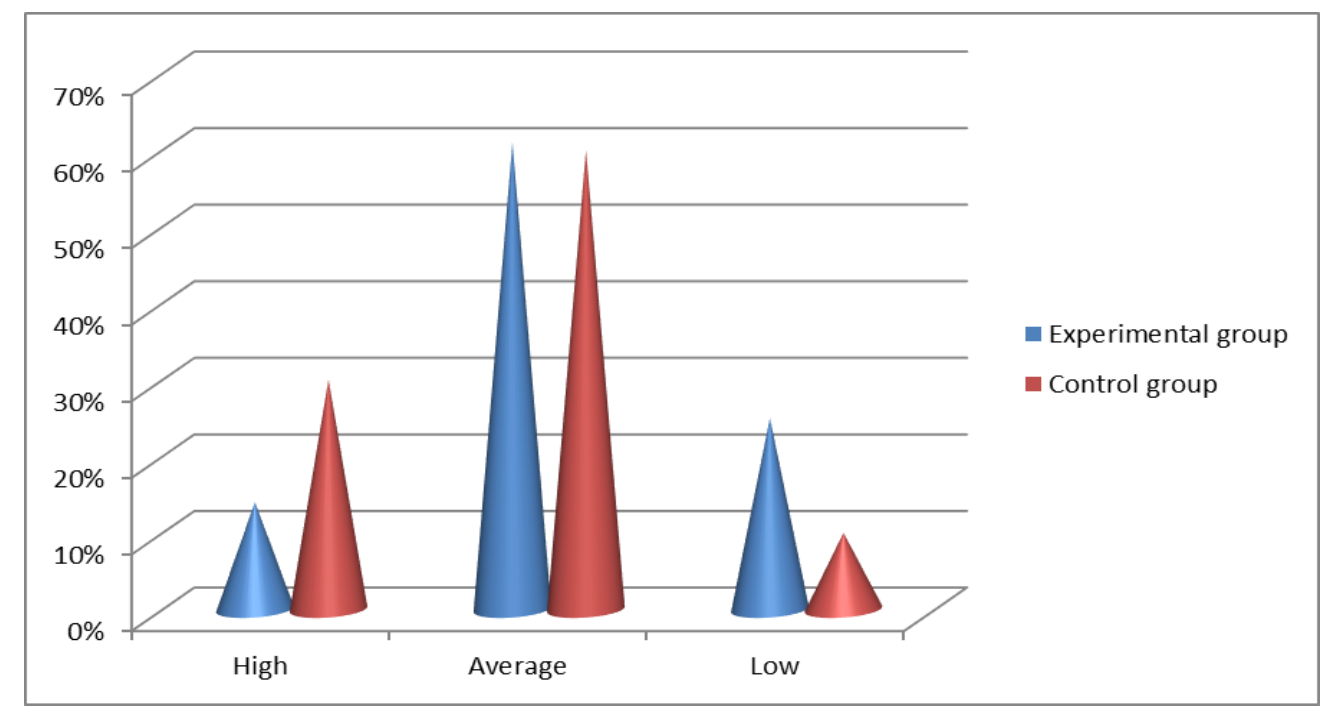

Figure 3. Distribution of the Respondents in the Experimental and Control Groups According to the Cognitive Competence Levels at the Beginning of the Experiment When Using the Project Method in the Teachers' Professional Activities

Source: Prepared by the authors based on the research results 


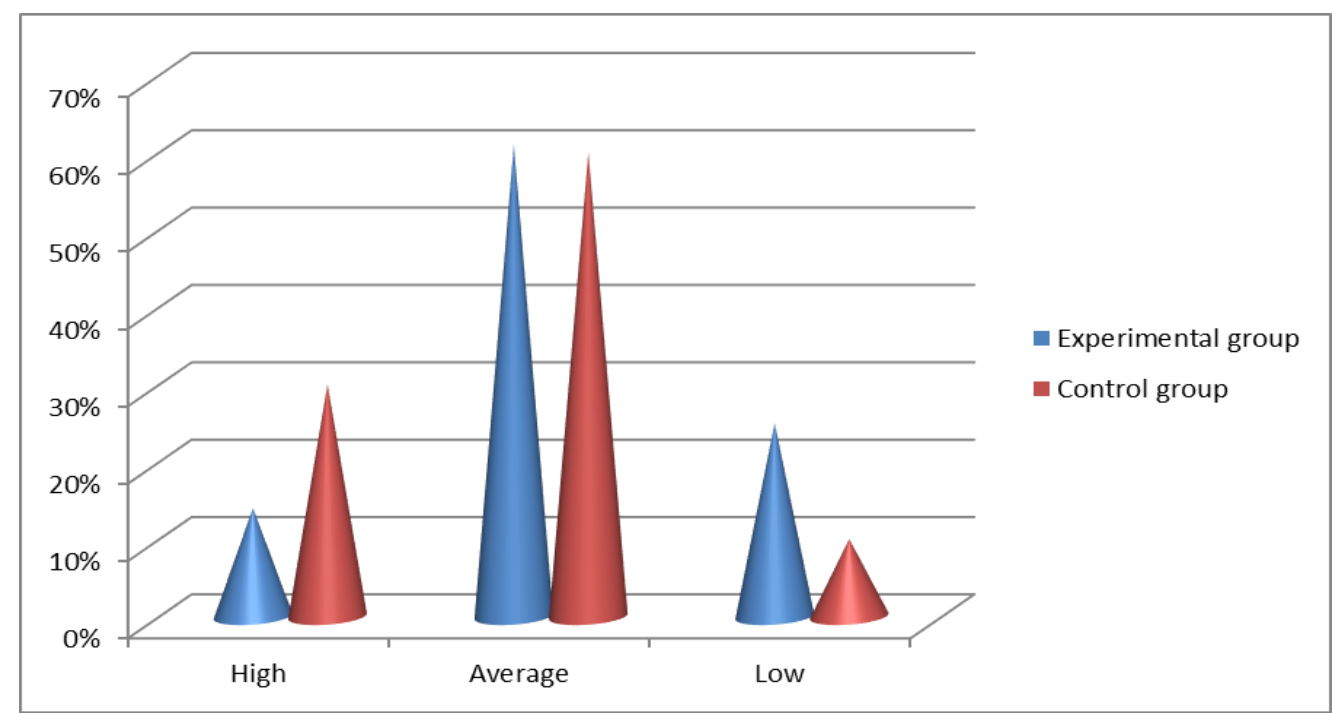

Figure 4. Distribution of the Respondents in the Experimental and Control Groups According to the Cognitive Competence Levels at the End of the Experiment When Using the Project Method in the Teachers' Professional Activities

Source: Prepared by the authors based on the research result

An efficiency indicator for the cognitive competence training in project activities was a positive change in the development level of each experimental group student. The processing of the research results was carried out using the $\chi 2$ parametric coefficient and gave grounds to assert that such an increase can be considered statistically significant. The results obtained indicate the effective implementation of the conceptual model for the cognitive competence training when using the project method by teachers. The $\chi 2$ distribution and verification of the $\mathrm{H} 0$ hypothesis are shown in Table 4.

Table 4. $\chi 2$ Coefficient Data

\begin{tabular}{lcccc}
\hline Value & $\begin{array}{c}\text { Control group at the } \\
\text { beginning of the } \\
\text { experiment }\end{array}$ & $\begin{array}{c}\text { Control group at the } \\
\text { end of the experiment }\end{array}$ & $\begin{array}{c}\text { Experimental group at the } \\
\text { beginning of the experiment }\end{array}$ & $\begin{array}{c}\text { Experimental group at the } \\
\text { end of the experiment }\end{array}$ \\
\hline 1 & 12 & 11 & 13 & 4 \\
2 & 17 & 6 & 5 & 19 \\
\hline
\end{tabular}

Source: Prepared by the authors based on the research results

From Table 4 it is clear that the chosen ordinal scale and the $\chi^{2}$ (chi-square) coefficient for testing the hypothesis, the data entry method - summary data, cognitive competence level values are presented in the column "values": high -2 , average -1 , low -0 . Based on the data analysis (Table 5), the characteristics of the compared samples were determined. The tabular value of the Kendall coefficient for $\mathrm{p}=0.05$ significance level corresponds to the Ткріт $=5.99$ value for the coefficient distribution according to the scheme $(2 * 3)$. 
Table 5. Kendall Coefficient Value for $\mathrm{p}=0.05$ Significance Level

\begin{tabular}{|c|c|c|c|c|}
\hline & $\begin{array}{l}\text { Control group at the } \\
\text { beginning of the } \\
\text { experiment }\end{array}$ & $\begin{array}{l}\text { Control group at } \\
\text { the end of the } \\
\text { experiment }\end{array}$ & $\begin{array}{l}\text { Experimental group at } \\
\text { the beginning of the } \\
\text { experiment }\end{array}$ & $\begin{array}{l}\text { Experimental group at } \\
\text { the end of the } \\
\text { experiment }\end{array}$ \\
\hline $\begin{array}{l}\text { Control group at the } \\
\text { beginning of the } \\
\text { experiment }\end{array}$ & & $\begin{array}{l}\text { Empirical value of } \\
\text { the chi-square } \\
\text { coefficient is } \\
0.6353 \text {, critical is } \\
5.991 .^{*}\end{array}$ & $\begin{array}{l}\text { Empirical value of the } \\
\text { chi-square coefficient is } \\
0.0328 \text {, critical is } \\
5.991 .^{*}\end{array}$ & $\begin{array}{l}\text { Empirical value of the } \\
\text { chi-square coefficient is } \\
6.1722 \text {, critical is } \\
5.991 . * *\end{array}$ \\
\hline $\begin{array}{l}\text { Control group at the end } \\
\text { of the experiment }\end{array}$ & $\begin{array}{l}\text { Empirical value of } \\
\text { the chi-square } \\
\text { coefficient is } 0.6353 \text {, } \\
\text { critical is 5.991.* }\end{array}$ & & $\begin{array}{l}\text { Empirical value of the } \\
\text { chi-square coefficient is } \\
0.9826 \text {, critical is } \\
5.991 .^{*}\end{array}$ & $\begin{array}{l}\text { Empirical value of the } \\
\text { chi-square coefficient is } \\
9.6536 \text {, critical is } \\
5.991 \text {. }^{* *}\end{array}$ \\
\hline $\begin{array}{l}\text { Experimental group at } \\
\text { the beginning of the } \\
\text { experiment }\end{array}$ & $\begin{array}{l}\text { Empirical value of } \\
\text { the chi-square } \\
\text { coefficient is } 0.0328 \text {, } \\
\text { critical is } 5.991 .^{*}\end{array}$ & $\begin{array}{l}\text { Empirical value of } \\
\text { the chi-square } \\
\text { coefficient is } \\
0.9826 \text {, critical is } \\
5.991 .^{*}\end{array}$ & & $\begin{array}{l}\text { Empirical value of the } \\
\text { chi-square coefficient is } \\
11.0813 \text {, critical is } \\
5.991 . * *\end{array}$ \\
\hline $\begin{array}{l}\text { Experimental group at } \\
\text { the end of the } \\
\text { experiment }\end{array}$ & $\begin{array}{l}\text { Empirical value of } \\
\text { the chi-square } \\
\text { coefficient is } 9.6536 \text {, } \\
\text { critical is 5.991.** }\end{array}$ & $\begin{array}{l}\text { Empirical value of } \\
\text { the chi-square } \\
\text { coefficient is } \\
6.1722 \text {, critical is } \\
5.991 \text {. }^{* *}\end{array}$ & $\begin{array}{l}\text { Empirical value of the } \\
\text { chi-square coefficient is } \\
11.0813 \text {, critical is } \\
5.991 .^{* *}\end{array}$ & \\
\hline
\end{tabular}

*Samples data coincide at a significance level of 0.05

**The reliability of the difference in samples characteristics is $95 \%$

Source: Prepared by the authors based on the research results

The obtained value of the statistical T coefficient is greater than the value of the critical coefficient (Table 5). This allows us to assert that the null hypothesis was not confirmed. Also, the control and experimental groups' data have a statistically significant deviation, which makes it possible to consider the proposed project method for the teachers' professional activities to be successful. The results of the experimental work clearly show the growth in the cognitive competences' level of the experimental group participants, which is presented in the diagram (Figure 5).

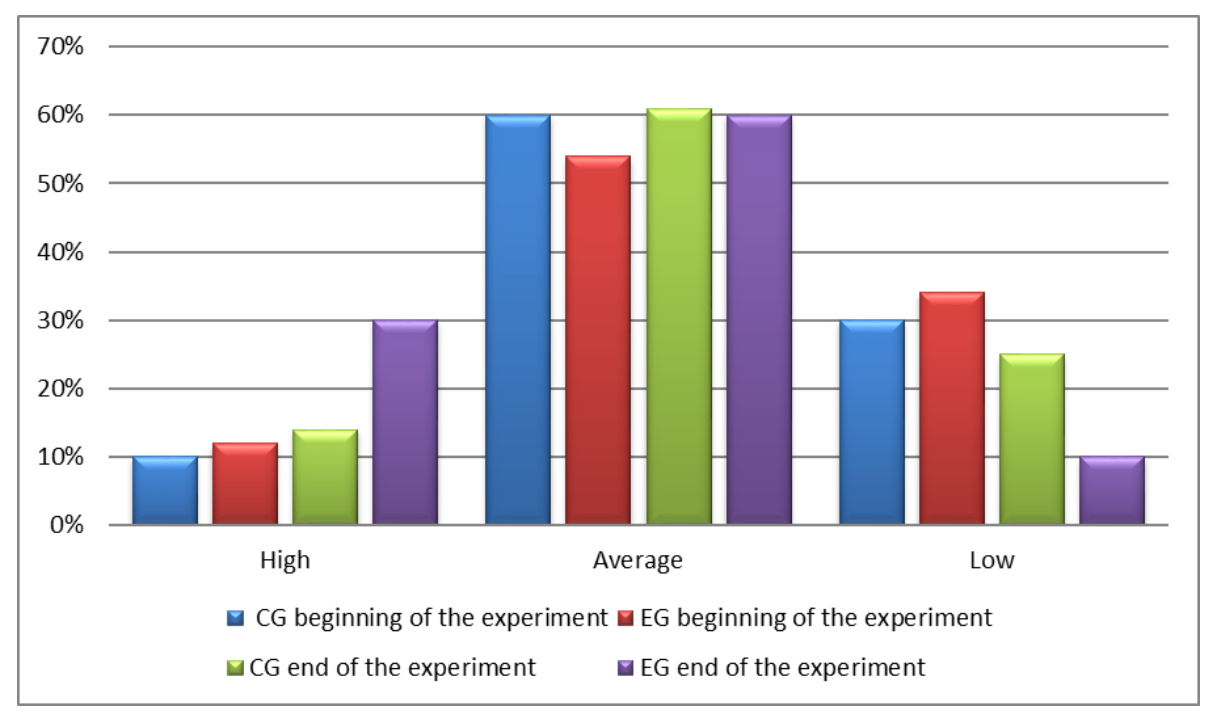

Figure 5. Summary Values of the Cognitive Competence Level Among the Respondents of the Control and Experimental Groups When Using the Project Method in the Teachers' Professional Activities

Source: Prepared by the authors based on the research results 
The diagram clearly shows that the best dynamics of the cognitive competence growth was observed in the experimental group, which organized students' project activities.

Table 6 presents the results of teachers' self-evaluation in the "knowledge" section, which includes such characteristics as:

the results that can be obtained after applying the new technique;

the essence of the new technique;

methods and techniques used by the teacher when implementing new technique;

methods of students' educational work.

Table 6. Results of Teachers' Self-Evaluation (knowledge and skills)

\begin{tabular}{llllllc}
\hline Sections & \multicolumn{2}{c}{ Number of teachers/score } & \multicolumn{3}{c}{$\begin{array}{c}\text { Average } \\
\text { score }\end{array}$} \\
\cline { 2 - 6 } & 0 & 1 & 2 & 3 & 4 & 3.5 \\
Knowledge & 0 & 0 & 0 & 32 & 45 & 3.3 \\
Ability to develop program-methodical support & 1 & 6 & 11 & 43 & 25 & 23 \\
Ability to solve practical problems & 2 & 8 & 9 & 35 & 2.9 \\
\hline
\end{tabular}

Source: Prepared by the authors based on the research results

So, as you can see from the table, most teachers rate their project method knowledge highly; fewer teachers are not fully confident that their knowledge will be enough. Figure 6 presents the results of teachers' self-evaluation in the "ability to develop program-methodical support" section.

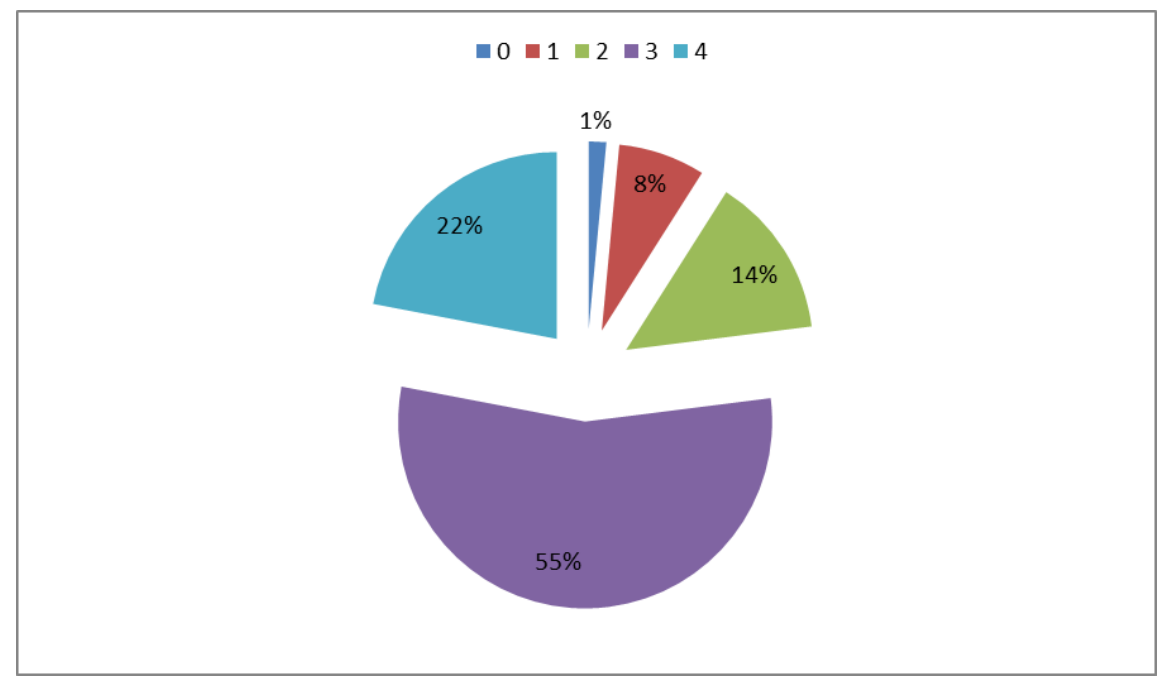

Figure 6. Results of Teachers' Self-Evaluation (ability to develop program-methodical support)

Source: Prepared by the authors based on the research result

As the diagram shows, most teachers doubt their level of skill in ability to develop program-methodical support. In addition, a fairly high percentage of teachers $(8 \%)$ noted that they have no idea or have little idea of this knowledge and skills. The greatest difficulties for teachers are caused by such skills as drawing up a task modified version (developing, socializing, etc.), as well as updating the educational projects' content, students' tasks for educational projects. Figure 7 shows the average results for the studied characteristics in the Teachers group. 


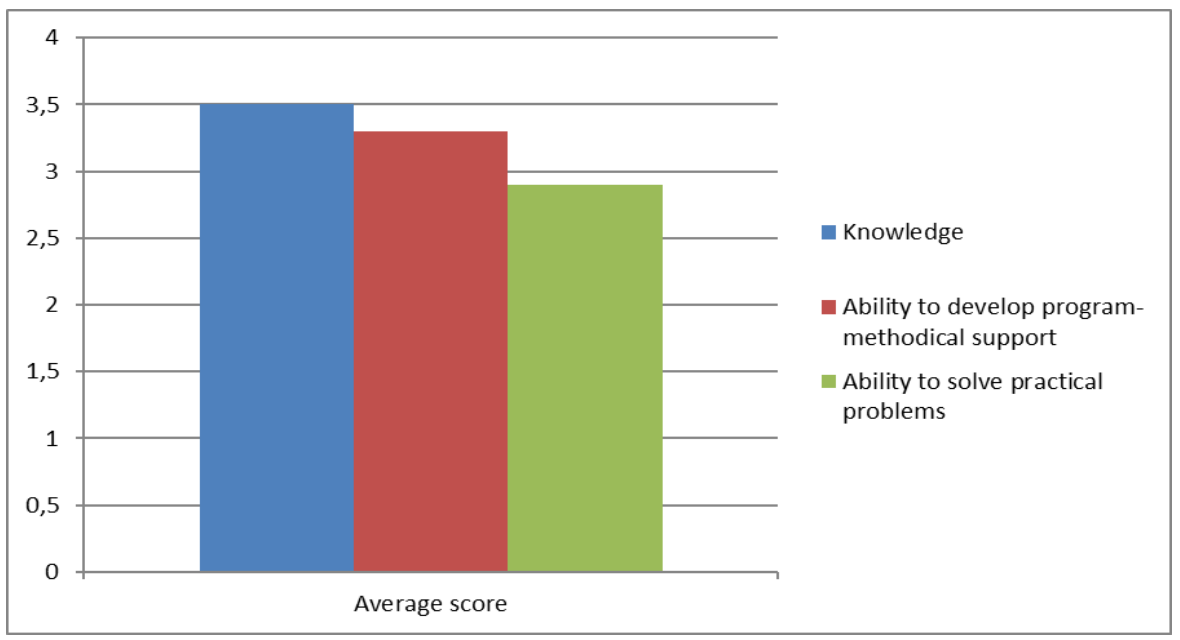

Figure 7. Average Results for the Studied Characteristics in the Teachers Group

Source: Prepared by the authors based on the research results

So, a general analysis of average results in terms of knowledge, skills to develop program-methodical support, etc., shows that most teachers have knowledge and skills, but they assess them as insufficient or doubt their efficiency.

\section{Discussion}

After processing the results obtained, the hypothesis was confirmed: the cognitive competencies training will be successful when combining pedagogical conditions. These conditions are:

- institutional environment for the professionally oriented tasks performance;

- interdisciplinary integration development, which determines the complex nature of the professional activity theoretical basis;

- a focus on cooperation between teachers and students during professional training.

Dustnazar et al. (2021) and Fraser et al. (2021) emphasize the need for teacher-student collaboration. The researchers note that the achievement of high efficiency of the project method is impossible without full cooperation of the educational process participants. Lee et al. (2021) emphasize the important role of teachers. According to researchers, teachers who are ready for education innovations play the main role in the project method implementation.

The leading pedagogical requirement for the students' project activities organization is the professional knowledge acquisition. Penaluna and Penaluna (2021) define the competencies training as the main goal of the project method usage. However, such researchers as Daminova (2020) and Bulent (2021) define teachers' workload reduction as the main task of project method implementation.

The most important condition for the project method usage is the organization of a collective activity (Kobets et al., 2019). It requires the selection and implementation of such an educational impact that fully meets student's personality characteristics to ensure maximum efficiency. In the study, this condition accomplishment contributed to the distribution of students in small groups, taking into account their interests, relationships, etc.

An important factor is positive motivation of the project activities' participants. Another essential condition for shaping the students' position is the continuous use of the project tasks system aimed at enhancing independent work. Bower et al. (2014) emphasize the important role of the project method when activating students' independent work. This helps to improve teachers' performance using workload reduction. At the same time, the project method proved itself to be an effective tool for educational process organization during distance learning. After the outbreak of the COVID-19 pandemic HEI teachers faced new challenges. The project method showed high rates in the educational competencies acquisition by the HEI students. This is evidenced by the studies of Drozdova et al. (2021). The main point for the successful acquisition of cognitive competencies when using the project method was the rise in the students' professional competence level. In the course of the study, it was noted that the activation of a creative orientation in project activities, characterized by an increase in the future specialists' professional activity, can be considered as a successful cognitive competence acquisition. The qualitative growth in the project tasks' performance 
turned out to be effective, showing the high level of conscious motivation to acquire knowledge. Such independent work contributes to the disclosure of creative abilities, morals acquisition that determine students' attitude to life. The importance of the project method in the educational activities is noted in the work of Kalamaj (2019). The author considers the project method to be a successful educational tool. Developing a number of qualities that students acquire while working on a project have a positive effect on their motivation. The analysis of the theoretical part and research results allowed us to draw up evaluation criteria and efficiency indicators for the application of the conceptual model in using the project method in the HEI teacher's professional activity.

\section{Conclusions}

The chosen topic is relevant due to the discrepancy between the need for the project management program-methodical support and insufficient development in pedagogical practice. When organizing the educational process in the control group, the listed pedagogical conditions were not provided by the teachers; all this had a significant impact on the results of the cognitive competence acquisition. Analysing the data of the experimental research, we state that, in general, the cognitive competence level of the control group participants increased by the end of the research. However, this increase is negligible. For example, the number of students with a high level of personality orientation increased only by $5.3 \%$, and those with a high level of creative activity - by $8.7 \%$. We cannot say that there was a significant decrease in the number of students with a low level of the aesthetic position at the end of the experiment. Thus, the number of students who showed high level of creative thinking in project activities became only $5.3 \%$ less than at the beginning of the experiment. A significant increase in the general level of cognitive competence acquisition in the experimental group in comparison with the control group is explained by purposeful work with students, taking into account special pedagogical conditions. At the practical level, all persons interested in education quality improvement can use the research. At a theoretical level, the work will be of interest to researchers studying the problems of project method implementation. Subsequent research can be directed to the project method development and implementation to improve the competencies acquisition, taking into account future professional activities.

\section{References}

Alvarez-Napagao, S., Ashmore, B., Barroso, M., Barrué, C., Beecks, C., Berns, F., Bosi, I., ... \& Ziliotti, L. (2021). Knowledge Project - Concept, Methodology and Innovations for Artificial Intelligence in Industry 4.0. IEEE 19th International Conference on Industrial Informatics (INDIN), 1-7, https://doi.org/10.1109/INDIN45523.2021.9557410.

Anishchenko, V., Artyushina, M., Gerland, T., Kulalaeva, V., \& Romanova, G. (2019). Theory and practice of project-based learning in vocational schools. Zhytomyr: Polissya. https://doi.org/10.32835/978-966-655-908-4/2019

Anisimova, E. (2020). Digital Literacy of Future Preschool Teachers. Journal of Social Studies Education Research, $11(1), 230-253$.

Arici, F., Yildirim, P., Caliklar, S.., \& Yilmaz, R. M. (2019). Research trends in the use of augmented reality in science education: Content and bibliometric mapping analysis. Computers \& Education, 142, 103647. https://doi.org/10.1016/j.compedu.2019.103647

Bakirova, H. B. (2021). Formation of terminological competence in ESP education. JournalNX - A Multidisciplinary Peer Reviewed Journal, 6(11), 63-68.

Bondar, G. (2021). The role of project activities in the formation of foreign language professional competence of non-language freelance students. Collection of scientific works Psychological and pedagogical problems of modern school, 1(5), 118-125. https://doi.org/10.31499/2706-6258.1(5).2021.235213

Bower, M., Howe, C., McCredie, N., Robinson, A., \& Grover, D. (2014). Augmented Reality in education - cases, places and potentials. Educational Media International, 51(1), 1-15. https://doi.org/10.1080/09523987.2014.889400

Boychuk, V. M. (2021). Application of innovative technologies in professional training of future teachers. VIII International Scientific and Practical Conference "Information technologies in education, science and production (ITONV-2021)", 79-82. $\quad$ Retrieved from http://itonv.lutsk-ntu.com.ua/files/2021/zbirnyk_itonv-2021.pdf\#page=79 
Bulent, A. (2021). Research methodology in critical mathematics education. International Journal of Research \& Method in Education, 44(2), 135-150. https://doi.org/10.1080/1743727X.2020.1728527

Carbonell Alcaina, C., Cardona, S. C., Domínguez-Candela, I., Fombuena, V., López Pérez, M. F., Lora-García, J., \& Sanchis, R. (2021). Project-Based Learning as a Coordination Methodology between Subjects in a Chemical Engineering Degree. INTED proceedings, 5965-5974. https://doi.org/10.21125/inted.2021.1193

Daminova, G. (2020). Interactive technologies in teaching a foreign language. Archives, 4(1). Retrieved from https://arxiv.adti.uz/index.php/arxiv/article/view/786

Drozdova, V., Rogulskaya, O., \& Rudnitskaya, K. (2021). Features of the use of project technologies in the process of distance learning of a foreign language in the Free Economic Zone. Scientific Bulletin of Uzhgorod University, 1(48), 127-132. https://doi.org/10.24144/2524-0609.2021.48.127-132

Dustnazar, O. K., Sayfiddin, S. B., \& Zukhra, K. J. (2021). Case-Study Method in Students Training. Annals of the Romanian Society for Cell Biology. Retrieved from https://www.annalsofrscb.ro/index.php/journal/article/view/3410

Fraser, D., Menzies, C., Mc Cormick, M., Muria, J. H., O'Hagan, S., Collins, F., McEwan, J., ... \& Trimble, N. A. (2021). Test and vaccinate or remove: Methodology and preliminary results from a badger intervention research project. VetRecord, 189(5). https://doi.org/10.1002/vetr.248

Gary, K. (2015). Project-based learning. Computer, 48(9), 98-100. https://doi.org/10.1109/MC.2015.268

Gontarenko, I. S. (2016). Formation of project competence of future teachers of humanities by means of Internet resources [Dissertation]. Glukhiv: Dovzhenko O. Glukhiv National Pedagogical University.

Ibáñez, M. B., \& Delgado-Kloos, C. (2018). Augmented reality for STEM learning: A systematic review. Computers \& Education, 123, 109-123.

Kalamaj, V. O. (2019). Psychological factors of efficiency of group project activity of students in the process of learning a foreign language [Dissertation]. Lutsk: Lesya Ukrainka Volyn National University.

Karabaevna, I. Z., Omonovich, K. D., Murodillaevich, K. N., Normuminovna, S. U., \& Mahmatqulovich, A. O. (2020). Formation of a system of methods of technical thinking future engineers. Journal of Critical Reviews. https://doi.org/10.31838/jcr.07.05.16110

Kobets, O., Dei, M., Shapovalova, K. G., Honcharov, A., \& Tsekhmister, Ya. (2019). Effectiveness of the program for development of prosecutor's ecological and legal consciousness. International Journal of Advanced Biotechnology and Research, Special Issue 1, 792-800.

Koval, O. Yu. (2019). Project methods of teaching a foreign language to university students. Pedagogy of creative personality formation in higher and general education schools, 63(2), 89-92. https://doi.org/10.32840/1992-5786.2019.63-2.18

Lee, S., Kim, H., Jeong, B., \& Yoon, J. (2021). A Training Method for Low Rank Convolutional Neural Networks Based on Alternating Tensor Compose-Decompose Method. Applied Sciences, 11(2), 643. http://dx.doi.org/10.3390/app11020643

Martin, P., \& Padula, P. (2018). Educational innovation at the university: comparison between problem-based learning and traditional lessons. International Journal of Higher Education Pedagogy, 34(3), 34-43. https://doi.org/10.4000/ripes.1574

Penaluna, A., \& Penaluna, K. (2021). In search of entrepreneurial competencies: Peripheral vision and multidisciplinary inspiration. Industry and Higher Education, 35(4), 471-484. https://doi.org/10.1177/0950422220963796

Plomp, V. R. (2020). Estimating links between latent variables using Structural Equation Modeling in R. Bachelor thesis. Retrieved from http://resolver.tudelft.nl/uuid:a3944cfc-a831-4d6c-ad0a-04605a0f1b91

Popel, M. V. (2018). Using Cocalc as a Training Tool for Mathematics Teachers' pre-Service Training. Information Technologies and Learning Tools, 68(6), 251-261.

Postholm, M. B. (2016). Collaboration between Teacher Educators and Schools to Enhance Development. European Journal of Teacher Education, 39(4), 452-470.

Soomro, K. A., Kale, U., Curtis, R., Akcaoglu, M., \& Bernstein, M. (2018). Development of an instrument to measure Faculty's information and communication technology access (FICTA). Education and Information 
Technologies, 23(1), 253-269. https://doi.org/10.1007/s10639-017-9599-9.

Weintraub, M. A. (2016). Pedagogical conditions for the introduction of project technologies in higher education institutions on the example of teaching the course "Methods of technical creativity". Young Scientist, 11(38), 419-421.

Zukhra, I., Ruzimurat, C., Gulzoda, I., Shokhida, A., \& Navruz, A. (2020). Competent model of practice-oriented education of students of the construction profile. Journal of Critical Reviews, 7(4), 437-441.

\section{Copyrights}

Copyright for this article is retained by the author(s), with first publication rights granted to the journal.

This is an open-access article distributed under the terms and conditions of the Creative Commons Attribution license (http://creativecommons.org/licenses/by/4.0/). 